\title{
Particularities of the European Union enlargement process
}

\author{
Iulia Andreea Bucur, Ph.D. Candidate, \\ University "Vasile Alecsandri" of Bacau, Romania
}

\begin{abstract}
The European integration model has proven to be so far a successful one, with a high consideration from the other countries of the world and their attempts to replicate its components and to learn from its experience of regional integration is perhaps the most sincere form of appreciation. Contemporary global economy knows various other models of economic integration, but none of the existing forms of regional integration was not up to the achievements of the EU which is distinguished primarily by the stage reached and function and its ability to create unity in the context of diversity. Irreversible process, and currently ongoing, and designed to produce positive results in perspective, the enlargement is one of the most significant factors of European construction success, always accompanying its history, marking the development, institutional structure, mode of cooperation and its policies. For these reasons, the present paper aims to approach the European integration model by the factors that influenced the enlargement and also by the course of events that are reflected in so-called "waves" of EU enlargement.
\end{abstract}

\section{Keywords}

European integration model, enlargement, determinants

\section{Introduction}

The European project is, first of all, a history product, beginning with the moment of end of WWII and created in order to ensure the peaceful settlement of conflicts of interest and to prevent another conflict of the same size. Looking over fifty years of European economic integration, we can say that this process was not uniform and is not a linear evolutionary path of Europe in the free trade zone in the single market, but it proved to be one characterized by an extremely complex process, with countless difficulties and uncertainties. Euro enthusiasm moments alternated with those of Euro skepticism and progress in the unification process did not always absolutely satisfy citizens or businesses from different Member States.

However, on the list of remarkable successes achieved by the European Union in the past fifty years we also found the high level of prosperity and economic stability reached by exploring the potential of increasing global interconnections in decades, becoming one of the main engines of global economy and an important model of inspiration for many regions of the world. Still present on the agenda of the European Union, the objective of fostering prosperity and maintain its economic stability both within and across the world, raises the question of its performance in an enlarged Union, since the very beginning European integration was not designed having so many countries and some of the new Member States belonging to the category of small, economically less developed, that recently regained their sovereignty.

Considering absolutely necessary and also undisguised the enlargement issue debut by presenting the main elements of influence that have always accompanied in 
different proportions this process, the next chapter analyzes the factors having a significant influence on the five enlargement stages.

\section{The determinants of EU Enlargement}

The phenomenon of European construction enlargement, and implicitly the internal market and economic cooperation, has inspired reforms and has consolidated common principles such as freedom, democracy, human rights and fundamental freedoms and contributes to increased prosperity and competitiveness. This allowed the enlarged Union to respond better to the challenges of globalization and simultaneously to become a major and more powerful player on the international scene.

Until now, the EU enlargement depth analyzes reveal a number of five factors playing a major role on the development and its outcome.

A prime determinant of the enlargement process is the $\boldsymbol{E} \boldsymbol{U}$ Treaties regulations as provisions which determine how to achieve it. Conditions for integration of any state in the European Union have been made with ever more precisely over its evolution, to provide clarity both their citizens and guidance to countries wishing to join.

The European enlargement subject has been approached and governed since the Treaty of Rome, in whose Preamble is clearly expressed the intention to create the necessary Union premises while the rest of Europe were invited to join ideas described in the Preamble. Moreover, Article 237 in the Treaty of Rome governing the procedure for accession of new Member States: "any European state may apply to become a member of the Community. It shall address its application to the Council, which after obtaining the opinion of the Commission, shall act by means of a unanimous vote". The adhesion criteria are covered by an agreement signed between Member States and the country wishes to join EU, agreement that must be ratified by all the states under the Constitution.

The above provisions have been changed since the first revision of the Treaty of Rome, the Single European Act in the coming period will be also required the European Parliament's agreement. We also found this regulation in the Treaty of Maastricht and later in the Treaty of Amsterdam. Article 49 of the Treaty on European Union stipulates that any European country can apply to become a member if it recognizes and respects the values of freedom, democracy and respects human rights, fundamental freedoms and the state law. This does not mean that all European countries have the intention or the EU must accept all applications. In addition, the Union reserves the right to decide when it is ready to receive them.

Treaty of Nice brings many new rules and regulations and in particular the so called "Protocol on enlargement" which stipulates first how to be composed of the European Union authorities, specifying the required majority in a Union of 25 and that the 27 Member States.

In the frame of EU enlargement regulations have been stipulated in the treaties from the beginning, Member States have not submitted, to the same extent and with the same consistency, efforts in order to extend the membership base. The main reason is the fear, fully justified, that a greater number of members involves a higher degree of heterogeneity with negative effect on interstate cooperation. Increasing heterogeneity as a result of EU enlargement process is often viewed as a risk to the single market and the euro, reason for which the applications for membership were always discussed in terms of possible negative repercussions of enlargement on deepening the integration process. This report tension between enlargement and deepening is a second factor of the process.

Member States special interests in certain areas, in other words that some branches of the economy could face a number of disadvantages from the emergence of best 
price products in the candidate countries, the "national" interests, meaning that the enlargement could come at the expense of certain Member States possibility to influence the decisions and the decision-making capacity of the EU system could suffer negative consequences from the enlargement process and stemming from fears expressed by Member States and other European countries, and the European Commission and European Parliament, are also factors of influence on EU enlargement phenomenon defining the behavior of community actors.

Besides the above mentioned factors, the EU enlargement process depends on three basic conditions: the internal preparation of candidate states, the EU internal preparation and the negotiations themselves.

\section{Previous EU enlargements and their main features}

The European construction initial plan take also into account the integration of new members, the founders of the Union having confidence in their idea to leave the door open to other European countries. Supporting countries with the vocation to become EU members was the Union's response to the European political changes in the last five decades, promoting economic growth, solidarity and strengthening the democratic forces of the countries emerging from dictatorship.

The first step in the enlargement process of European economic integration is the extension to the north that began with the UK application for membership after four years since the Treaty of Rome entry into force, namely in 1961. After that it took quite a period of time, until 1973 when the United Kingdom, Denmark and Ireland were able to integrate into the European Community. The cause of central importance was the French President Charles de Gaulle opposition, but we can not exclude other factors of economic and especially political reasons deriving from concern about the close interdependence of Great Britain to the United States that could acquire a nonnegligible influence on the development of European Community. This is in total opposition to French President de Gaulle's vision about how you have to show: a form of cooperation of sovereign national states, which left the American sphere of influence.

Meanwhile, the attitude of Member States on the accession of Great Britain was marked by conflicts between the visions of the future development of European Community. France, however, could not prevent long-term enlargement. Thus, with the occasion of the Hague summit in 1969, de Gaulle's successor, Georges Pompidou has agreed to resume negotiations on the extension of the $\mathrm{EC}$, in contrast to other countries France received permission to complete the project and develop the common agricultural policy - a so-called "package deal" in which were taken into account the national interests of all Member States. Furthermore, entered the game special areas interests as possible serious of France (agricultural policy).

The accession of United Kingdom, Denmark and Ireland has given quite different meanings to role of the European Community. Both the UK and Denmark, comprising primarily from an economic community which hoped to profit, and the problem of supplementing the measures to limit the sovereignty of both countries was not taken into discussion.

While there were still doubts upon the UK integration was not a good choice, extension to the south of the European Community held in two phases: 1981 with the inclusion of Greece and 1986 the accession year of Spain and Portugal, was regarded, in unison, as something positive and necessary in terms of political and strategic. The weaknesses deriving practical extension south of the process itself, were the economic consequences, the economic development of the three states being clearly below the average Community and institutional heterogeneity due to increased and substantial 
increase in the number of member countries that raised the efficiency of the Community institutions and decision-making capacity.

Analyzing the second wave of enlargement of the European Community in terms of determinants, we can say that it was influenced by a particular factors combination.

Treaties regulations within the meaning of the unanimous approval of Member States on accession of new countries, have led to internal problems of the EC in the early ' 80 s, consisting of differences of interests and vision of the future evolution of the integration process, and significantly delayed the negotiations. Only after a summit in Fontainebleau in 1984, the EC Member States were unable to reach a specific date on the accession of Spain and Portugal (January the $1^{\text {st }}, 1986$ ). Another significant factor in the process of enlargement to the south is the tension between enlargement and deepening, not possible without first achieving the second by the Single European Act in 1987 and the domestic market. In this context, some Member States and the European Commission adopted a series of measures to redress the Community. These initiatives have resulted in so-called internal market program, through which, by the end of 1992, were to be removed all trade restrictions which still exist between Member States, and in particular all non-tariff trade restrictions, to be that of achieving a true common market, real.

The other three drivers of behavior resulting from enlargement of the European Community Member States have also played an important role in the second stage of the process: area interests, particularly in the common agricultural policy, national interests the future development of the European Community as interstate and focusing more on the economic vision of Great Britain and Denmark or towards deepening cooperation including political dimension that looked and vision of Germany, skepticism over EU decision-making capacity of the system in parallel with increasing degree of heterogeneity in the aftermath of the second wave of enlargement.

The smooth accession was undoubtedly the third one from January the $1^{\text {st }}, 1995$ which included Austria, Sweden and Finland and the EFTA enlargement, the main reason consists of very close economic relations between EFTA and the Community that had been governed since 1972 by bilateral trade agreements, replaced later in January 1994 the European Economic Area (EEA). Many of Community regulations, particularly in the internal market, were applied to the three states, and also having a relatively high economic level, through the EEA agreement, before becoming members of the EC. EFTA countries increased interest for certain topics of reference, and obtain a higher degree of transparency or social policy and environmental policy, the importance of political status in the loss of neutral countries following the cessation of the conflict between east and west on policies that create new impulses . A common element in their first three waves of enlargement of the European Community is that all took place in the context of deepening the integration process. If the first three waves of enlargement were considered successful, the following two stages of EU enlargement marked by two times - in 2004 and 2007 - are seen as unprecedented in terms of scale and diversity that characterizes them and involving high levels of risk in terms economically, socially and politically.

A key factor for the initiation of the fourth wave of EU enlargement in 2004 was the Berlin Wall fell in 1989 and communist regimes in Central and Eastern European countries (CEEC), plus the change processes, the transition to a functioning market economy in those countries faced with economic and social problems rather worrying, problems that resulted in their desire to capture the help and support of Western countries. In this regard, a first response from the European Community in the early ' 90 was the intensification of diplomatic relations with a considerable number of CEEC, concluding Association Agreements or Europe Agreements. The essential 
aim expressed by the Europe Agreements was to facilitate and develop trade and cooperation between the EU and associated countries through a large European market, which was to include all these states. In this they were required to align with the Member States by adopting rules for the internal market and restructuring the national economy, receiving at the same time, the Union, the financial support under various schemes. By end of 1990 after 10 of the Europe Agreements with Central and Eastern European countries in addition to those already existing in Turkey (1963), Malta (1970) and Cyprus (1972) was recognized objective associated countries to become members of European Union objectively confirmed by their individual applications.

Although initially it was a simple association, financial support and the assertion of issues of common interest, they have changed considerably with the Council's decision in Copenhagen in June 1993 at which point the associated CEEC accession could applies only the context in which they were proof that the so-called "Copenhagen criteria": the existence of a stable institutional framework that guarantees democracy, rule of law, human rights and protection of minorities, the existence of a functioning market economy and ability to cope competitive pressures and forces the EU internal market, the ability to assume obligations of membership, including to accept and act in accordance with the aims of political, economic and monetary union.

Going on the same idea, the European Council in Madrid in December 1995 underlined the need to adapt the administrative structures of the candidate in order to ensure implementation of EU legislation (Acquis communautaire, meaning all the EU rules, practices and presumptions. It basically means what has been achieved so far. This included the Single European market and the Maastricht provisions on the Economic and Monetary Union) into national legislation and its effective application through the administrative structures and adequate legal. Thus, the Copenhagen criteria be added a fourth criterion: the administrative capacity for implementing the Community's vitae.

After the formal request for accession of CEEC in the period 1994-1996, the European Council called, in light of the Treaties, the European Commission to draw up reports on the situation of each candidate country in order to see the extent that they meet the accession criteria and capacity to assume their obligations under state obtaining EU membership. These reports were submitted by the European Commission in July 1997 as "Agenda 2000 - for a stronger Union and more stable". Agenda 2000 is a reference document for the enlargement process and for the deepening, the emphasis on European integration.

Milestones in the EU enlargement process are: Board of Luxembourg in December 1997 and Council in Helsinki in December 1999. Luxembourg European Council (December 1997), which said that "enlargement requires strengthening and improving the functioning of institutions previously under the provisions of the Treaty of Amsterdam", is when the EU Member States decided to start concrete negotiations for accession with the Czech Republic, Estonia, Poland, Hungary, Slovenia and Cyprus. Negotiations with the "first wave" candidate countries, the so-called "Luxembourg group" were opened on March 31, 1998. Council in Helsinki (December 1999) considers the accession to the Union subject to compliance with the Copenhagen criteria, candidate had to "share values and goals as they are set out in the Treaties" and decided to start accession negotiations with the "second wave", so-called "Helsinki group": Bulgaria, Romania, Latvia, Lithuania, Slovakia and Malta. Officially, negotiations with them were opened on February 15, 2000 in Brussels.

European Commission published a policy paper in November 2000, on the enlargement of the Union, including the "map" of enlargements from 2002 that was 
an "insurance policy" on the EU's ability to get among them at the end of 2002, new members. This document was approved by the European Council of Nice, in which was initiated and the Treaty of Nice (ratified on February 26, 2001) that regulate the organization of the European Union to deal with, in terms of institutional future enlargements.

At the European Council in Laeken in December 15, 2001 has made the conclusion that the enlargement process is irrevocable, underlining the clear intention of the European Union to end the current accession negotiations by the end of 2002. This was done at the European Council in Copenhagen in December 2002, at which negotiations were completed only 10 of the 12 states, setting it as the date of accession on May 1, 2004 to also be established and issues the financial period 20042006 (the first difficult years for the EU-25).

Signing of the Accession Treaty on April 16, 2003, is the next moment in the evolution process of EU enlargement towards Central and Eastern Europe. The content can be found Treaty rules regarding institutional participation of 10 new members in the period between its conclusion and until formal accession on May $1^{\text {st }}$, 2004. During this period, the candidate countries had observer status in the forums Council, with the right to speak but not to vote.

So, the first stage of expansion was achieved on May 1, 2004 for the 10 countries: Cyprus, Czech Republic, Estonia, Hungary, Latvia, Lithuania, Malta, Poland, Slovakia and Slovenia. The fourth wave of EU enlargement in the May 2004 is the most ambitious project of the EU European nations and the elements that you customize are linked on the one hand the large number of countries involved in negotiations with the EU accession conditions, which became members of the most performing groups in the world and integrationist second notable discrepancies in the level of their development from that of other Member States but also from that of former candidate countries, current EU.

Romania and Bulgaria have completed negotiations until 2004, the accession treaties to be drawn from the July 2004 deadline for accession by setting January 1, 2007 and the inclusion of three safeguard clause economy, internal market and JHA (Justice and Home Affairs). Later signing the accession treaty in April 2005, the two countries have entered a system of monitoring and screening in the previous report of September 26, 2006 was advanced on January $1^{\text {st }}, 2007$ as currently certainly of both countries joined the EU.

The fifth wave of enlargement is undoubtedly the most spectacular, the reason being close to Europe as the European dream was conceived, but also the most difficult, expensive and full of unexpected compared the first four extensions for the following reasons: lack of a mature market economy for most Central and Eastern European countries, different stages of consolidation of macroeconomic stability and achieving structural reforms that are found new members, which can be translated by different degrees of preparation for accession, the economic development of new members, except Cyprus, Malta and Slovenia, are well below the EU average, average GDP per inhabitant representing only $40 \%$ that of the 15 Member States, to be $70 \%$ as that of Spain and Portugal, at their accession in 1986, which creates additional pressure for access to structural funds, the fifth wave of enlargement has place after completing the single market, removing internal border controls, which narrows the single market regulations in order not to affect the integrity, the number of countries that joined the reform requires common institutions and common policies as decision-making process must to remain effective, some common policies, implemented in its current form, would require a much larger EU budget.

The current situation of the EU enlargement process involves on the one hand the existence of candidates, being to make the European perspective in EU membership: 
Croatia, Turkey (EU starting negotiations with both countries on October 3, 2005 for accession) and the former Yugoslav Republic of Macedonia and on the other hand there is the potential candidate countries, other Western Balkan states - Albania, Bosnia - Herzegovina, Montenegro and Serbia (including Kosovo under Resolution 1244 UN Security Council), countries that undertake efforts to meet the conditions necessary next step in the process of accession.

\section{Conclusions}

The context in which the EU enlargement process is marked by three challenges related to economic performance, internal cohesion and external role, so that its success depends on how to respond. If viewed as a new start can be a catalyst for solving some of the most pressing problems of Europe. While western European countries stability and democracy are translated into benefits, not only in terms of security, but also in prosperity, economic growth in these countries means opportunities for businesses large, investment, increased trade, increased employment, for the central and eastern Europe, the unification symbolizes the values that have aspired for half a century, and while their final option for the values of democracy and market economy.

Enlargement of European economic integration is, so far, a success story for the European Union and the European continent as a whole, contributing to strengthening security in Europe and demonstrating their ability to transform into genuine democratic candidate that the rules functioning market economy and which are true partners in facing of common challenges.

\section{References}

1. Cameron, F., (2005), The EU Model of Integration - Relevance Elsewhere?, Jean Monnet/Robert Schuman Paper Series, Vol.5, No.37

2. Dinu, M., Socol. C., Marinas M., (2007), Modelul european de integrare, Ediţia a II-a, Ed. Economică, Bucharest

3. Gunor, G., (2007), Ever Expanding Union? A Closer Look at the European Union's Enlargement Agenda, EUMA, Vol.4, No.15

4. Ignat I., (2002), Uniunea Europeană. De la Piaţa Comună la moneda unică, Ed. Economică, Bucureşti

5. Kok, W., (2003), Enlarging the European Union. Achievements and Challenges, Report to the European Commission

6. Pascariu G.C., (2006) Integrare economică europeană - Curs Jean Monnet, Universitatea „Al.I. Cuza”, Centrul de Studii Europene, Iași

7. http://www.bis.org

8. http://dadalos-europe.org

9. http://ec.europa.eu

10. http://eur-lex.europa.eu

11. http://www.ier.ro 